\title{
Cytogenetic Studies in Three Species of the Genus Oligosarcus
}

\author{
Marceléia Rubert and Vladimir Pavan Margarido* \\ Universidade Estadual do Oeste do Paraná; Centro de Ciências Biológicas e da Saúde; vpmargarido@unioeste.br; \\ Rua Universitária, 2069; 85814-110; Cascavel - PR - Brasil
}

\begin{abstract}
Karyotypic studies were carried out on three species of the genus Oligosarcus: O. paranensis, O. pintoi, and O. longisrostris. All of them showed a diploid number of 50 chromosomes and the same karyotypic formulae $(4 M+$ $10 S M+16 S T+20 A)$. Silver nitrate staining revealed single NORs in O. longirostris and multiple NORs in O. paranensis and $\mathrm{O}$. pintoi. Heterochromatin seemed to play an important role in the chromosomal diversification of these species. Based on cytogenetical data, speciation hypotheses within this group were proposed, reinforcing the importance of chromosomal studies for a better understanding of evolution within the genus Oligosarcus, as well as within the family Characidae.
\end{abstract}

Key words: Cytogenetic studies, Oligosarcus, Acestrorhynchinae, chromosome banding

\section{INTRODUCTION}

Among all freshwater fish families of South America, Characidae is the largest one, comprising approximately 170 genus and 885 species (Nelson, 1994), with 400 species occurring in Brazil (Britski, 1972). The family Characidae presents a wide distribution, ranging from United States to South Argentina, besides the African continent (Lucena, 1993). Because of its wide distribution, species richness, and morphological diversity, the establishment of phyletic relationships in this family is quite difficult (Lucena, 1993). Approximately 30 subfamilies belong to the family Characidae (Britski et al., 1988). The subfamily Acestrorhynchinae comprises two genera: Acestrorhynchus and Oligosarcus. Species from this subfamily are distributed along Eastern and Southeastern rivers of Brazil and Uruguay, as well as at São Francisco and Paraguay River basins (Menezes, 1969). The genus Oligosarcus has about 16 species, characterized as agile predators, preying on fish and insects (Menezes, 1987; Miquelarena and Protogino, 1996). They can be found in rivers from the Paraná-Paraguay basins and in coastal rivers from Southern and Southeastern Brazil (Menezes, 1969). They occur predominantly in shaded areas of about $0,40 \mathrm{~m}$ in depth, surrounded by vegetation, with sandy or rocky bottoms (Caramaschi, 1986).

Karyotypic studies in the family Characidae have shown a great variation in the chromosomal number, which ranges from 28 chromosomes in Hemigrammus (Scheel, 1973) to 64 chromosomes in Serrasalmus hollandi (Muramoto et al., 1968). The family also presents a great variability in relation to the number of nucleolar organizer regions (NORs), ranging from one to thirteen NOR-bearing chromosomal pairs (Rocon-Stange and Almeida-Toledo, 1993). The chromosomal

\footnotetext{
${ }^{*}$ Author for correspondence
} 
variability of Characidae species can be determined by the occurrence of Robertsonian rearrangements, as suggested by Morelli et al. (1983). On the other hand, Arefjev (1990) suggests such variability to the polyphyletic arrangement of the family. Cytogenetic studies in the genus Oligosarcus are scarce and restricted to the species $O$. hepsetus, $O$. jenynsii, $O$. macrolepis, $O$. paranensis, and $O$. pintoi. All of them present a same diploid number, equal to 50 chromosomes, with interspecific variation in the karyotypic formulae (Falcão and Bertollo, 1985; Oliveira et al., 1988; Mortati and Dias, 2002a; Martinez and Júlio Jr, 2002). Inter- and intraspecific variation of NOR number was also observed, ranging from one to three NOR-bearing chromosomal pairs (Hattori et al., 2002; Mortati and Dias, 2002b; Martinez and Júlio Jr, 2002). Differences in the pattern of heterochromatin distribution were also reported (Hattori et al., 2002; Mortati and Dias, 2002a).

The aim of the present paper was characterizing cytogenetically three species of the genus Oligosarcus and, based on these results, to propose some hypotheses about the phylogenetic relationships in Acestrorhynchinae and Characidae, as well.

\section{MATERIALS AND METHODS}

Mitotic chromosomes were obtained from kidney cells (Bertollo et al., 1978) of O. paranensis (12 males and 21 females) and $O$. pintoi (6 males and 8 females), collected at Tunas river, belonging to the Piquiri river basin (Nova Laranjeiras, PR), and O. longirostris (14 males and 9 females) collected at Iguaçu river (Quedas do Iguaçu, PR). Silver nitrate staining was performed to detect Ag-NOR sites (Howell and Black, 1980), and C-banding was performed to reveal heterochromatin segments (Sumner, 1972).

\section{RESULTS}

The three species analyzed showed a diploid number of 50 chromosomes, with a same karyotypic formulae, composed by 4 metacentric (M), 10 submetacentric (SM), 16 subtelocentric (ST), and 20 acrocentric chromosomes (A) in both sexes (Fig. 1). Silver nitrate staining identified multiple NORs in $O$. paranensis, involving one acrocentric chromosomal pair $\left(17^{\text {th }}\right)$ bearing terminal NORs on short arms, observed in all metaphases, plus two to four non-homologous NOR-bearing chromosomes (Fig. 2a). In O. pintoi, NORs were located on short arms of an acrocentric chromosomal pair $\left(21^{\text {st }}\right)$, observed in all metaphases, plus one to two NOR-bearing chromosomes (Fig. 2b). Only a single pair bearing Ag-NOR sites was identified in O. longirostris, located terminally on short arms of the $21^{\text {st }}$ acrocentric chromosomal pair (Fig. 2c).

$O$. paranensis presented more heterochromatin richness than $O$. pintoi and $O$. longirostris. $O$. paranensis showed a large amount of heterochromatin, with conspicuous blocks located terminally on the long arms of acrocentric chromosomes from the pairs 16, 17, 18, 19, 20, 21, and 22 (Fig. 3a); in $O$. pintoi, heterochromatin was associated to NORs in the acrocentric chromosomes from the pair 21 and in the short arms of one chromosome from the $2^{\text {nd }}$ pair (Fig. $3 b)$. In $O$. longirostris, C-bands were located on acrocentric chromosomes from the pair 21, equivalent to NORs (Fig. 3c).

\section{DISCUSSION}

The present results obtained in the species $O$. paranensis, $O$. pintoi, and $O$. longirostris corroborate those previously reported for $O$. pintoi (Falcão and Bertollo, 1985; Hattori et al., 2002) and O. paranensis (Mortati and Dias, 2000, 2002a,b; Martinez and Júlio Jr, 2002). A diploid number of 50 chromosomes was characteristic for Acestrorhynchinae, observed in both genera, Oligosarcus and Acestrorhynchus (Falcão and Bertollo, 1985; Martinez and Júlio Jr, 2002). The three species studied also showed the same karyotypic formulae, 4M-10SM-16ST-20A, revealing a great similarity of chromosomal macrostructure. Comparing the data here obtained to that from other analyzed populations of $O$. paranensis (Mortati and Dias, 2002a; Martinez and Júlio $\mathrm{Jr}, 2002$ ) and $O$. pintoi (Falcão and Bertollo, 1985), distinct karyotypic formulae were observed (Table 1). The numerical maintenance coupled with variation in karyotypic formulae could represent the occurrence of structural rearrangements, like inversion and/or translocation, which played an important role on the evolution of this group. 

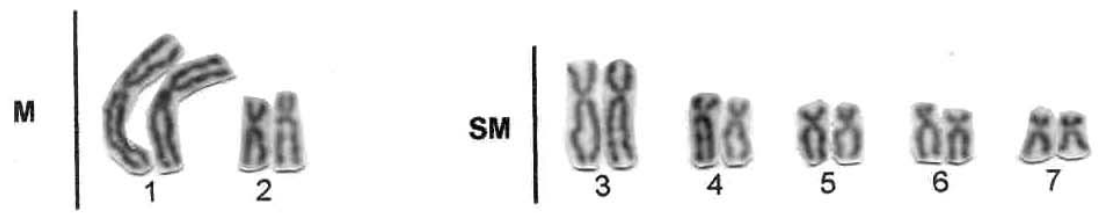

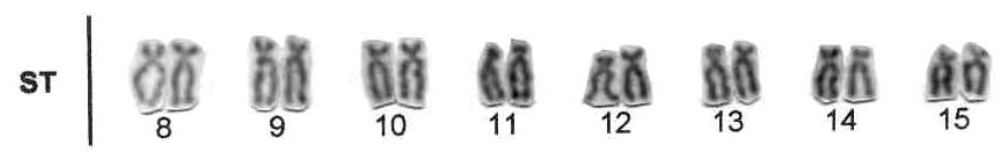

A

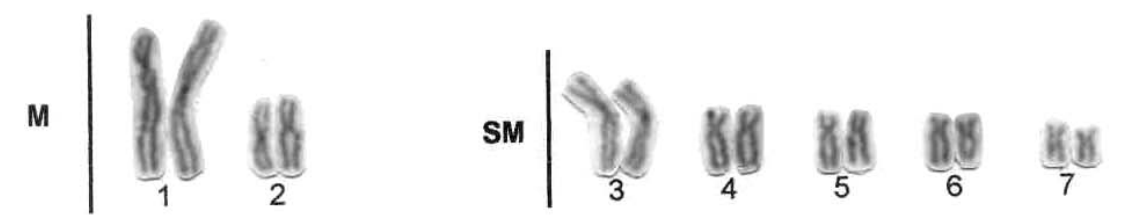

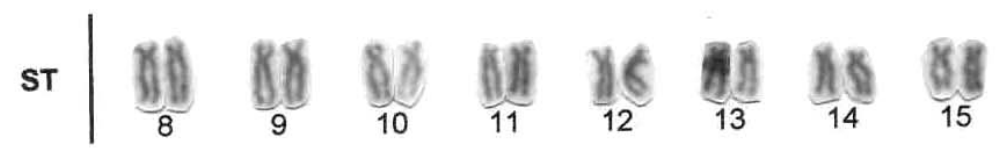

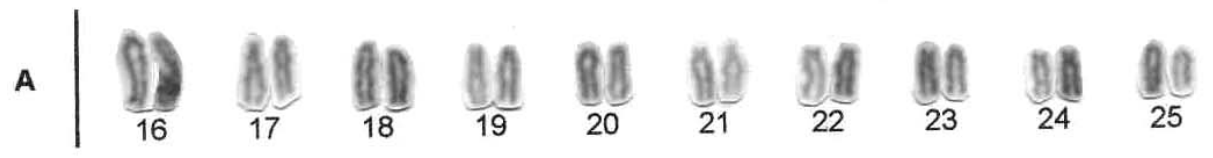

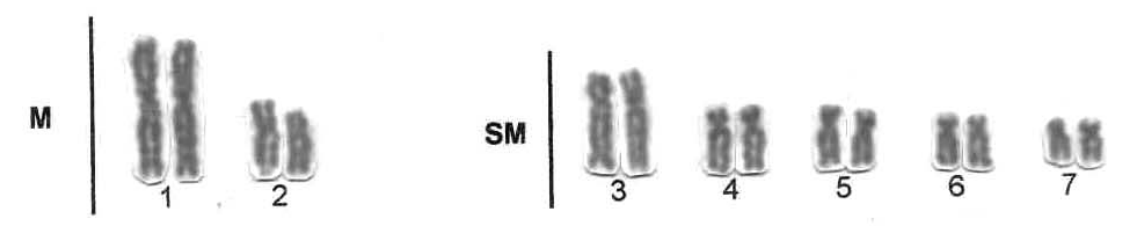

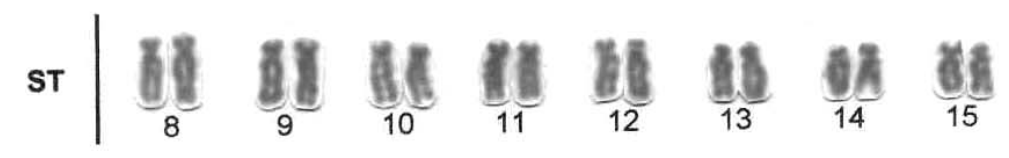

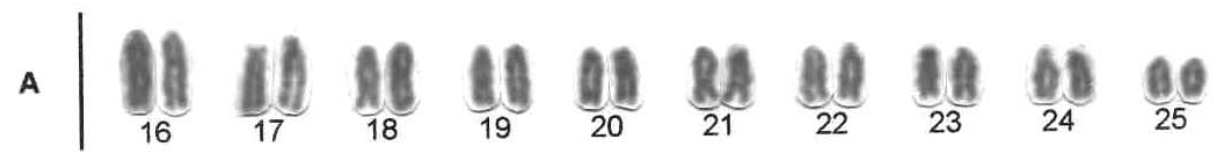

Figure 1 - Conventional Giemsa-stained karyotypes of (a) Oligosarcus paranensis, (b) Oligosarcus pintoi and (c) Oligosarcus longirostris. 

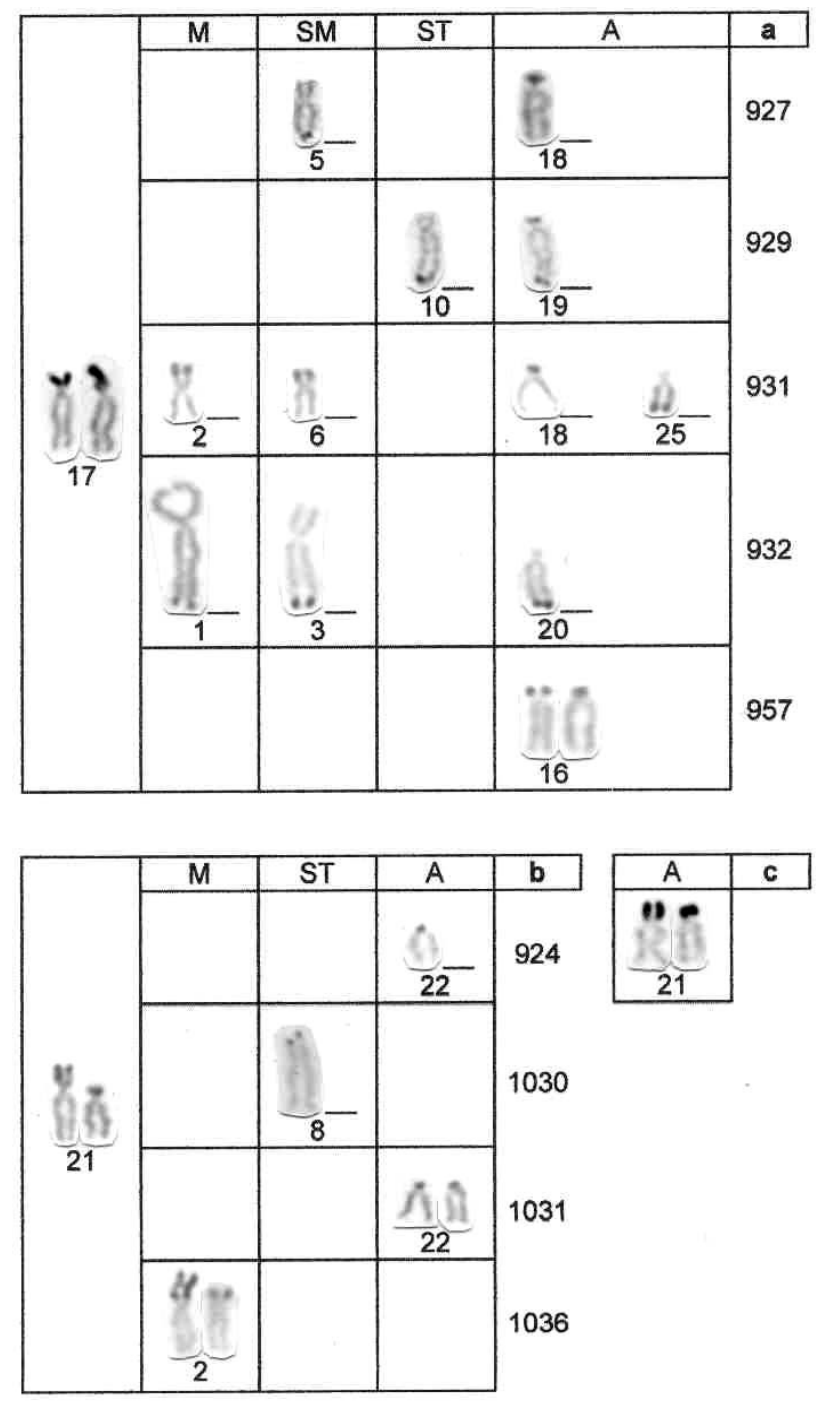

Figure 2 - NOR-bearing pair chromosomes detected in (a) Oligosarcus paranensis (animals 927, 929, 931, 932, 957), (b) Oligosarcus pintoi (animals 924, 1030, 1031, 1036) and (c) Oligosarcus longirostris $(\mathrm{M}=$ metacentric chromosomes, $\mathrm{SM}=$ submetacentric chromosomes, $\mathrm{ST}=$ subtelocentric chromosomes, $\mathrm{A}=$ acrocentric chromosomes).

According to Falcão and Bertollo (1985), the occurrence of addiction or deletion in some chromosomal regions could not be discarded. Other hypothesis is attributed to technical difficulties, concerning to the determination of the exact centromere position, as well as the relative condensation shown by some chromosomes. In some cases, the arm ratio value was very close to the limits established for chromosome classification, as observed in other studies (Feldberg and Bertollo, 1985; Margarido and Galetti, 1996). According to Oliveira et al. (1988) and Almeida-Toledo, Foresti and Oliveira (1993), chromosomal macrostructure variations among different populations could be related to their mobility and size, i.e., fish groups that presented higher vagility and large populational sizes tended to conserve the karyotypic macrostructure, such as Prochilodontidae (Bertollo et al., 1986), Curimatidae (Venere and Galetti, 1989), Anostomidae (Galetti et al., 1991), Salmininae and Bryconinae (Margarido and Galetti, 1999) - all migratory groups (Godoy, 1975). However, groups that presented reduced mobility and small 
populations have distinct karyotypes, such as Hoplias (Bertollo et al., 1978; Bertollo et al., 1986; Born et al., 2000) Astyanax scabripinnis (Moreira-Filho and Bertollo, 1991) and Corydoras (Oliveira et al., 1993), species that lacked a migratory behavior (Godoy, 1975). Isolation provided the opportunity for each population to evolve independently (Moreira-Filho and Bertollo, 1991).

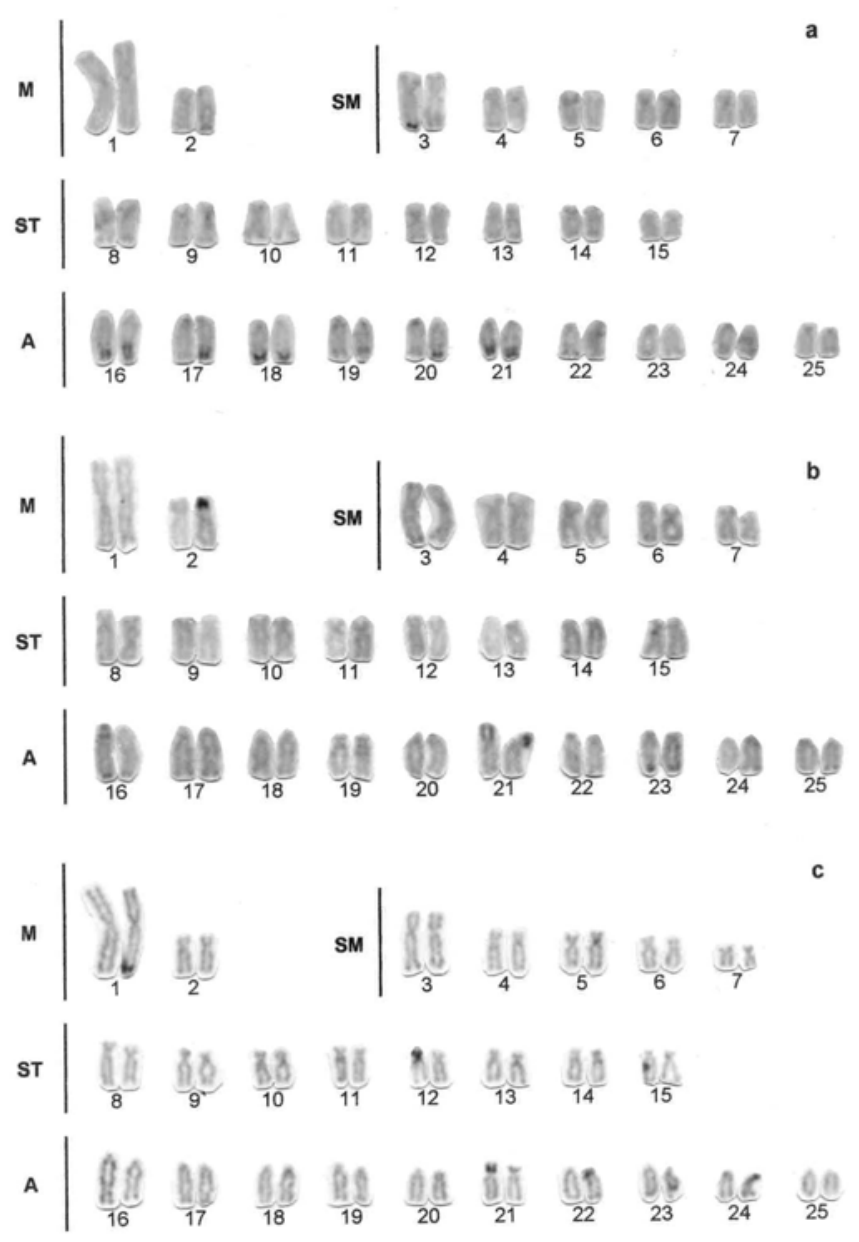

Figure 3- C-banded karyotypes of (a) Oligosarcus paranensis, (b) Oligosarcus pintoi and (c) Oligosarcus longirostris.

Table 1 - Karyotype data of Oligosarcus species.

\begin{tabular}{|c|c|c|c|c|}
\hline Species & Locality & Karyo & otype & Ref. \\
\hline & (River-State) & M SM & ST A & \\
\hline O. hepsetus & Juquiá-SP & 28 & 22 & 1 \\
\hline O. jenynsii & Ipiranga-SP & 28 & 22 & 1 \\
\hline O. longirostris & Iguaçu-PR & $4 \quad 10$ & $16 \quad 20$ & 4 \\
\hline O. macrolepis & Turvo-MG & 28 & 22 & 1 \\
\hline O. paranensis & Tibagi-PR & 226 & $8 \quad 14$ & 2 \\
\hline & Paraná-PR & $2 \quad 26$ & $8 \quad 14$ & 3 \\
\hline & Piquiri-PR & $4 \quad 10$ & $16 \quad 20$ & 4 \\
\hline O. pintoi & Mogi-Guaçu-SP & 24 & 26 & 1 \\
\hline & Piquiri-PR & $4 \quad 10$ & $16 \quad 20$ & 4 \\
\hline
\end{tabular}

M-metacentric; SM-submetacentric; ST-subtelocentric; A-acrocentric; Ref-Reference; 1-Falcão and Bertollo (1985); 2-Mortati and Dias (2002a); 3-Martinez and Júlio Jr (2002); 4-Present paper. 
By silver nitrate staining, only $O$. longirostris presented a single NOR pair. $O$. paranensis and $O$. pintoi showed multiple NORs, with intraspecific variation related to number and location. Similar results were reported in other populations of $O$. paranensis (Mortati and Dias, 2002b; Martinez and Júlio Jr, 2002) and $O$. pintoi (Hattori et al., 2002). Such numerical variation could be related either to differential NOR activity (Miller et al., 1976; Pendás et al., 1993) and/or to different numbers of rDNA cistrons among individuals. There were, at least, two hypotheses about the chromosomal evolution of Characidae: Arefjev (1990) suggested an ancestral karyotype composed by $2 \mathrm{n}=50-52$ chromosomes, with all chromosomes types, but presenting few acrocentric chromosomes; Miyazawa (1997) proposed that the ancestral karyotype number would be $2 \mathrm{n}=54$ chromosomes with a high number of acrocentric chromosomes and a single NOR-pair. The presence of bi-armed chromosomes would represent a derived karyotype, and as long as the number of acrocentric chromosomes increased, more ancestral would be the karyotype. A new hypothesis is presented here. According to Lucena (1993), Erythrinidae was considered the most ancestral group within Characiformes, and lacerdae-group would be the most basal lineage of Erythrinidae. Hoplias lacerdae showed a karyotype composed by 50 bi-armed chromosomes (Bertollo 1996; Morelli, 1998). The presence of meta-submetacentric chromosomes and a single NOR-pair was reported in several Characiformes groups (Anostomidae, Galetti et al., 1984; Parodontidae, Moreira-Filho et al., 1985; Jesus and Moreira-Filho, 2000; Prochilodontidae, Pauls and Bertollo, 1990; Curimatidae, Venere and Galetti, 1989; Feldberg et al., 1992; Martins et al., 1996), and the presence of ST-A chromosomes in these groups were an exception, instead of the rule (Portela et al., 1988). Many subfamilies belonging to Characidae have a diploid number of 50 chromosomes (Acestrorhynchinae, Falcão and Bertollo, 1985; Characidiinae, Miyazawa and Galetti, 1994; Bryconinae and Salmininae, Margarido and Galetti, 1996; Stethaprioninae, Pfister et al., 1997), and some of them presented a single NOR-pair (Acestrorhynchinae, Bryconinae, Salmininae, Stethaprioninae). Thus, apparently an ancestral karyotype for Characiformes composed by 50 bi-armed chromosomes and single NORs existed, and the Characidae subfamilies, that shared these features, would have a basal position in this family. The large variation in both diploid $(2 \mathrm{n}=28-64$ chromosomes) and NOR (one to thirteen pairs) numbers in Characidae could be explained by the artificial grouping amongst members from this family, stressing the necessity of further phylogenetic studies in order to propose a correct phyletic arrangement of Characidae.

C-banding analyses revealed different patterns of heterochromatin distribution among the three analyzed species. The heterochromatin distribution of $O$. pintoi was more similar to that from $O$. longirostris, both characterized by small amounts of NOR-associated heterochromatin. $O$. paranensis presented a large amount of heterochromatin widespread over several chromosomes, displaying conspicuous terminal heterochromatin blocks, thus suggesting a mechanism of dispersion by translocations. According to Souza et al. (2001), the presence of heterochromatin on telomeric and centromeric regions facilitated the exchange among others nonhomologous chromosomes, with posterior amplification. It has been frequently suggested that heterochromatin plays an important role in the fish chromosomal evolution (Galetti et al., 1991; Margarido and Galetti, 1999, among others).

Caramaschi (1986) collected specimens of $O$. paranensis and $O$. pintoi at $3^{\text {rd }}$ and $4^{\text {th }}$ order rivers (stream), not occurring in the main stream, which leaded to the isolation of different populations and facilitated the fixation of chromosomal rearrangements. On the other hand, $O$. longirostris was widely distributed at Iguaçu river (Severi and Cordeiro, 1994), inhabiting the main stream, providing a high gene flow among populations; therefore, sharing similar cytogenetic features. The Tunas and Iguaçu rivers should provide differential conditions that associated with geographical isolation, determined distinct evolutionary pathways in local populations and the presence of peculiar features, enough to differentiate them from other populations at Paraná-Piquiri system. This could explain the great karyotypic variability found among the different populations of $O$. paranensis and $O$. pinto $i$ studied by far.

The results obtained in this work confirmed the stable karyotype among Acestrorhynchinae. Furthermore, Oligosarcus, comprising species with several acrocentric chromosomes and multiple NORs, should represent a derived position within Acestrorhynchinae. Moreover, 
Acestrorhynchus species, which showed a karyotype composed by bi-armed chromosomes and single NORs should represent the basal position, corroborating the hypothesis proposed by Lucena (1993).

\section{ACKNOWLEDGMENTS}

The authors are grateful to Carla S. Pavanelli, Center of Research in Limnology, Ichthyology and Aquaculture (Nupelia - UEM), for identifying the species studied, and to Aureo N. Terres and to Geraldo S. Zientarski for their help in fish capture. This work was supported by UNIOESTE-Campus Cascavel.

\section{RESUMO}

No presente trabalho foram analisadas três espécies do gênero Oligosarcus: $O$. paranensis, $O$. pintoi e $O$. longirostris. As três espécies possuem número diplóide de 50 cromossomos e mesma fórmula cariotípica $(4 \mathrm{M}+10 \mathrm{SM}+16 \mathrm{ST}+20 \mathrm{~A})$. A impregnação por nitrato de prata revelou RONs simples para $O$. longirostris e RONs múltiplas para $O$. paranensis e $O$. pintoi. A heterocromatina desempenha um importante papel na caracterização das espécies. Hipóteses sobre a especiação do grupo são apresentadas com base nos dados citogenéticos obtidos neste trabalho, reforçando a importância destes estudos para uma melhor compreensão da evolução tanto do gênero Oligosarcus quanto da família Characidae.

\section{REFERENCES}

Almeida-Toledo, L. F.; Foresti, F. and Oliveira, C. (1993), A citogenética de peixes no Brasil. Paper presented at $10^{\text {th }}$ Congresso Brasileiro de Ictiologia, 9-13 February, São Paulo, São Paulo.

Arefjev, V. A. (1990), Problems of karyotypic variability in the family Characidae (Pisces, Characiformes) with the description of somatic karyotypes for six species of tetras. Caryologia, 43, 305-319.

Bertollo, L. A. C.; Takahashi, C. S. and Moreira-Filho, O. (1978), Cytotaxonomic considerations on Hoplias lacerdae (Pisces, Erythrinidae). Brazil. J. Genet., 1, 103-120.
Bertollo, L. A. C.; Moreira-Filho, O. and Galetti, P. M. (1986), Cytogenetics and taxonomy: considerations based on chromosome studies of freswater fish. $J$. Fish Biol., 28, 153-159.

Bertollo, L. A. C. (1996), The nucleolar organizer regions of Erythrinidae fish. An uncommon situation in the genus Hoplias. Cytologia, 61, 75-81.

Born, G. G.; Bertollo, L. A. C.; Dergan, J. A.; Fenocchio, A. S. and Moreira-Filho, O. (2000), A biodiversity approach in the neotropical Erythrinidae fish, Hoplias malabaricus. Karyotypic survey, geographic distribution of cytotypes and cytotaxonomic considerations. Chromosome Research, 8, 603-613.

Britski, H. A. (1972), Peixes de água doce do Estado de São Paulo: Sistemática. In: Poluição e Piscicultura. Faculdade de Saúde Pública da Universidade de São Paulo e Instituto de Pesca da C.P.R.N. da Secretaria da Agricultura, São Paulo, pp 79-108.

Britski, H. A.; Sato, Y. and Rosa, A. B. S. (1988), Manual de identificação de peixes da região de Três Marias (com chaves de identificação para os peixes da bacia do São Francisco). 3 ed. Brasília: CODEVASF.

Caramaschi, E. P. (1986), Distribuição da ictiofauna de riachos das bacias do Tietê e do Paranapanema, junto ao divisor de águas (Botucatu, SP). PhD Thesis, Universidade Federal de São Carlos, São Carlos, Brazil.

Falcão, J. N. and Bertollo, L. A. C. (1985), Chromosome characterization in Acestrorhynchinae and Cynopotaminae (Pisces, Characidae). J. Fish Biol., 27, 603-610.

Feldberg, E. and Bertollo, L. A. C. (1985), Karyotypes of 10 species of neotropical cichlids (Pisces, Perciformes). Caryologia, 38, 257-268.

Feldberg, E.; Porto, J. I. R. and Bertollo, L. A. C. (1992), Karyotype evolution in Curimatidae (Teleostei, Characiformes) of the Amazon region. I. Studies on the genera Curimata, Psectrogaster, Steindachnerina and Curimatella. Brazil. J. Genet., 15, 369-383.

Galetti Jr, P. M.; Foresti, F.; Bertollo, L. A. C. and Moreira-Filho, O. (1984), Characterization of eight species of Anostomidae (Cypriniformes) fish on the basis of the nucleolar organizing regions. Caryologia, 37, 401-406.

Galetti Jr, P. M.; Mestriner, C. A.; Venere, P. C. and Foresti, F. (1991), Heterochromatin and Karyotypic reorganization in fish of the family Anostomidae (Characiformes). Cytogenetic Cell Genetic, 56, 116-121.

Godoy, M. P. (1975), Peixes do Brasil, subordem Characoidei da bacia do rio Mogi-Guaçu. Editora Franciscana, Piracicaba. 
Hattori, R. S.; Lopes, C. E. and Almeida-Toledo, L. F. (2002), Estudos citogenéticos comparativos em três espécies do gênero Oligosarcus (Pisces, Characidae). Paper presented at $9^{\text {th }}$ Simpósio de Citogenética e Genética de Peixes, 16-18 October, Maringá, Paraná.

Howell, W. M. and Black, D. A. (1980), Controlled silver-staining of nucleolus organizer regions with a protective colloidal developer: a I-step method. Experientia, 36, 1014-1015.

Jesus, C. M. and Moreira-Filho, O. (2000), Karyotypes of three species of Parodon (Teleostei: Parodontidae). Ichthyol. Explor. Freshwaters, 11, 75-80.

Lucena, C. A. S. (1993), Estudo filogenético da família Characidae com uma discussão dos grupos naturais propostos (Teleostei, Ostariophysi, Characiformes). PhD Thesis, Universidade de São Paulo, São Paulo, Brazil.

Margarido, V. P. and Galetti Jr, P. M. (1996), Chromosome studies in fish of the genus Brycon (Characiformes, Characidae, Bryconinae). Cytobios, 85, 219-228.

Margarido, V. P. and Galetti Jr, P. M. (1999), Heterochromatin patterns and karyotype relationships within and between the genera Brycon and Salminus (Pisces, Characidae). Genetics and Molecular Biology, 22, 357-361.

Martinez, E. R. M. and Júlio Jr, H. F. (2002), Análise citogenética de Oligosarcus cf paranensis (Characidae, Acestrorhynchinae) do rio Mourão e de Acestrorhynchus lacustris (Characidae, Acestrorhynchinae) do rio Paraná. Paper presented at $9^{\text {th }}$ Simpósio de Citogenética e Genética de Peixes, 16-18 October, Maringá, Paraná.

Martins, C.; Giuliano-Caetano, L. and Dias, A. L. (1996), Occurrence of a B chromosome in Cyphocharax modesta (Pisces, Curimatidae). Cytobios, 85, 247-253.

Menezes, N. A., (1969), Systematic and evolution of the tribe Acestrorhynchinae. Arq. de Zool, 18, 1-150.

Menezes, N. A., (1987), Três novas espécies de Oligosarcus Günther, 1864 e redefinição taxonômica das demais espécies do Gênero (Osteichthyes, Teleostei, Characidae). Boll. Zool., 11, 1-39.

Miquelarena, A. M. and Protogino, L. C. (1996), Una nueva especie de Oligosarcus (Teleostei, Characidae) de la cuenca del rio Paraná, Missiones, Argentina. Iheringia. Ser. Zool., 80, 111-116.

Miller, D. A.; Dev, V. G.; Tantravahi, R. and Miller, O. J. (1976), Suppression of human nucleolus organizer in mouse-human somatic hybrid cells. Exp. Cell Res., 101, 235-243.

Miyazawa, C. S. and Galetti Jr, P. M. (1994), First cytogenetical studies in Characidium species (Pisces, Characiformes, Characidiinae). Cytologia, 59, 73-79.
Miyazawa, C. S. (1997), Citogenética de caracídeos da bacia do rio Paraguai: Análises citotaxonômicas evolutivas e considerações biogeográficas. $\mathrm{PhD}$ Thesis, Universidade Federal de São Carlos, São Carlos, São Paulo, Brazil.

Moreira-Filho, O.; Bertollo, L. A. C. and Galetti Jr, P. M. (1985), Karyotipic studies of some species of family Parodontidae (Pisces, Cypriniformes). Caryologia, 38, 47-55.

Moreira-Filho, O. and Bertollo, L. A. C. (1991), Astyanax scabripinnis (Pisces, Characidae): a specie complex. Brazil. J. Genet., 14, 331-357.

Morelli, S. (1998), Citogenética evolutiva em espécies do gênero Hoplias, grupo lacerdae. Macroestrutura cariotípica, heterocromatina e regiões organizadoras de nucléolo. PhD Thesis, Universidade Federal de São Carlos, São Carlos, São Paulo, Brazil.

Morelli, S.; Bertollo, L. A. C.; Foresti, F.; MoreiraFilho, O. and Toledo-Filho, S. A. (1983), Cytogenetic considerations on the genus Astyanax (Pisces, Characidae). I. Karyotypic variability. Caryologia, 36, 235-244.

Mortati, A. F. and Dias, A. L. (2000), Dados cariotípicos preliminares de Oligosarcus paranensis (Pisces, Acestrorhynchinae) coletados na bacia do rio Tibagi, PR. Paper presented at $5^{\text {th }}$ Encontro Paranaense de Genética, 17-18 August, Maringá, Paraná.

Mortati, A. F. and Dias, A. L. (2002a), Análise do padrão de distribuição da heterocromatina constitutiva em duas populações de Oligosarcus paranensis (Pisces, Characidae), da bacia do rio Tibagi-PR. Paper presented at $9^{\text {th }}$ Simpósio de Citogenética e Genética de Peixes, 16-18 October, Maringá, Paraná.

Mortati, A. F. and Dias, A. L. (2002b), Variação na distribuição das NORs entre duas populações de Oligosarcus paranensis (Pisces, Characidae), da bacia do rio Tibagi-PR. Paper presented at $9^{\text {th }}$ Simpósio de Citogenética e Genética de Peixes, 16-18 October, Maringá, Paraná.

Muramoto, J.; Ohno, S. and Atkin, N. B. (1968), On the diploid stage of the fish order Ostariophysi. Chromosoma, 24, 59-66.

Nelson, J. S. (1994), Fishes of the world. 3rd edition. John Wiley and Sons Inc, New York.

Oliveira, C.; Almeida-Toledo, L. F.; Foresti, F.; Britski, H. A. and Toledo-Filho, S. A. (1988), Chromosome formulae of Neotropical freshwater fishes. Brazil. J. Genet., 11, 577-624.

Oliveira, C.; Almeida-Toledo, L. F.; Mori, L. and Toledo-Filho, A. S. (1993), Cytogenetic and DNA content studies of armoured catfishes of the genus Corydoras (Pisces, Siluriformes, Callichthyidae) from the southeast coast of Brazil. Brazil. J. Genetic., 16, 617-629. 
Pauls, E. and Bertollo, L. A. C. (1990), Distribution of a supranumerary chromosome system and aspects of karyotypic evolution in genus Prochilodus (Pisces, Prochilodontidae). Genetica, 81, 117-123.

Pendás, A. M.; Morán, P. and Garcia-Vasquez, E. (1993), Multi-chromosomal location of ribossomal RNA genes and heterochromatin association in brown trout. Chromosome Research, 1, 63-67.

Pfister, S. C.; Moreira-Filho, O. and Bertollo, L. A. C. (1997), Cytogenetic studies in Orthospinus franciscensis (Pisces, Characidae, Stethaprioninae) and some considerations about karyotype evolution of the group. Cytobios, 91, 97-101.

Portela, A. L. B. S.; Galetti, P. M. and Bertollo, L. A. C. (1988), Considerations on the chromosome evolution of Tetragonopterinae (Pisces, Characidae). Brazil. J. Genet., 11, 307-316.

Rocon-Stange, E. A. and Almeida-Toledo, L. F. (1993), Supernumerary B chromosomes restricted to males in Astyanax scabripinnis (Pisces, Characidae). Brazil. J. Genet., 16, 601-615.

Scheel, J. J. (1973), Fish chromosomes and their evolution. Internal Report of Danmarks Akvarium, Charlottenlund, Denmark.
Severi, W. and Cordeiro, A. A. M. (1994), Catálogo de peixes da bacia do rio Iguaçu. Curitiba: IAP/GTZ.

Souza, I. L.; Galián, J.; De La Rúa, P.; Bertollo, L. A. C. and Moreira-Filho, O. (2001), Non-random distribution of the GC-rich heterochromatin and nucleolar rDNA sites on Astyanax scabripinnis chromosomes. Cytologia, 66, 85-91.

Sumner, A. T. (1972), A simple techinique for demonstrating centromeric heterocromatin. Experimental Cell Research, 75, 304-306.

Venere, P. C. and Galetti Jr, P. M. (1989), Chromosome evolution and phylogenetic relationships of some neotropical Characiformes of the family Curimatidae. Brazil. J. Genet., 12, 17-25.
Received: November 10, 2004 Revised: May 30, 2005; Accepted: September 05, 2006. 
PÁGINA

EM

BRANCO 